\title{
Abundance of sucking insect pests of Bt cotton and their natural enemies under different intercropping systems
}

\author{
D.R. KADAM*1, D.B. KADAM ${ }^{1}$ AND S.M. UMATE ${ }^{2}$
}

\author{
${ }^{1}$ Department of Agriculture Entomology, College of Agriculture, Vasantrao Naik Marathwada Krishi Vidyapeeth, \\ PARBHANI (M.S.) INDIA \\ Email : pushpabhagyalakshmi@gmail.com \\ ${ }^{2}$ Department of Agriculture Botany, Vasantrao Naik Marathwada Krishi Vidyapeeth, PARBHANI (M.S.) INDIA
}

\begin{abstract}
The abundance of sucking pest of Bt cotton was studied under different intercropping systems during Kharif 2013 at VNMKV, Parbhani, Maharashtra. The results revealed that all intercropping systems were superior over sole cotton in respect of sucking pest population. Cotton + greengram and cotton + blackgram were the most effective intercropping systems that recorded lowest incidence of sucking pests followed by cotton + soybean and cotton + sesamum.
\end{abstract}

Key words : Bt cotton, Intercropping, Sucking pests

How to cite this paper : Kadam, D.R., Kadam, D.B. and Umate, S.M. (2014). Abundance of sucking insect pests of Bt cotton and their natural enemies under different intercropping systems. Asian J. Bio. Sci., 9 (2) : 284-287. 